\title{
WeChat: A New Medium of the Ideological and Political Education
}

\author{
Xinghua Tong ${ }^{1, \text { a }}$ \\ ${ }^{1}$ Ideological and Political Department of Wenshan University, Wenshan City, Yunnan Province, \\ China, 663000 \\ a email:
}

Keywords: WeChat, Colleges and Universities, Ideological and Political Education, Feasibility, Countermeasures

\begin{abstract}
As a new type of communication tool, WeChat has been sought by college students for a long period of time, and its coverage is more broad than the blog, which may replace the text messages and phone calls. With the help of a variety of new media, college ideological and political education has made a significant progress, and the WeChat's popularity has brought us a new opportunity for its further development. Based on the author's work experience for many years, first of all, this paper analyzes the feasibility of the college student ideological and political education by WeChat, and then discusses the influences, finally, puts forward the countermeasures to carry out the ideological and political education for college students by WeChat new media .
\end{abstract}

\section{Introduction}

Using WeChat to carry out ideological and political education of college students has become an inevitable trend in the development of ideological and political work. Making a reasonable planning and control for the WeChat, positively interacting with students and organizing topic discussion are the new position to carry out ideological and political education work. Facing the challenges brought by WeChat to the ideological and political education of young college students, reasonably putting forward the relevant countermeasures is the current ideological and political education issues to be resolved under the new media environment.

\section{The Feasibility of the College Student Ideological and Political Education by WeChat}

WeChat applications have a hardware foundation. Almost every college student holds a cell phone or other communication tools, and mobile phone has become necessary for college students life activities. WeChat is very popular among college students, therefore, it will provide the basis for the use of WeChat's ideological and political education work. In addition, in the modern university campus, whether it is a living area or teaching area, it is covered by the $3 \mathrm{G}$ network or WIFI signal, so that it provides a network base for college students using WeChat.

WeChat itself has a very strong communication advantage. WeChat can quickly send a language, text, pictures, video and other information to the friends through the network, and it supports multi group chating, supports the establishment of public accounts, so a variety of communication methods attract students' attention. WeChat only charges internet traffic, so it can help students to save a lot of phone charges. WeChat's low cost is also an important factor in the application of college students love. WeChat integrates the functions of QQ and micro-blog, 
supporting for receiving and sending files, supporting for receiving QQ offline messages, supporting to find the micro signaland check the phone address book. Using WeChat to carry out ideological and political education of college students, colleges and universities can make full use of WeChat's interactive, convenient and timely reacting, and it is able to understand the students' ideological trends and use WeChat to communicate effectively, so it is useful to eliminate the sense of distance between teachers and students from the psychological sense, further to strengthen the education effect.

WeChat is easy to carry out ideological and Political Education. WeChat has received a deep recognition of College students, and it meets the students' curiosity to get the group sense of belonging, therefore, WeChat has become a popular culture beyond the technology and social culture. College students hope to declare express emotions, values, outlook on life and world outlook through WeChat. Ideological and political workers can find the ideological trends of college students in time, understand their political hot spots, and pay attention to their comments on the topic through WeChat, so as to quickly put forward countermeasures to solve the possible psychological problems of college students. The using of WeChat public platform can achieve the spread of information. Ideological and political workers can inform good deeds, do the students' opinion survey questionnaire, upload and share the latest campus dynamics, and timely release and deal with campus emergencies by WeChat.

\section{The Influence of WeChat on the Ideological and Political Education of College Students}

Positive impact. WeChat has opened up a new way forIdeological and political education. The traditional ideological and political education of college students is a face to face teaching, due to the single limit of the content of the educator, the educated lack the opportunity to speak when they receive education, but WeChat just can make college students ideological and political education work more reasonable. At the same time, WeChat's interactive ways break the uneven relationship, which demonstrates the subjectivity of college students.

Negative influence. First, WeChat information inhibits the traditional classroom teaching effect. At present, the main way to the ideological and political education of college students is the traditional classroom teaching mode and this one-sided information dissemination results in a certain resistance to college students. If the classical theory of Ideological and political education does not occupy the brain of College students, their minds will have a large number of WeChat network information and the concept behind the idea. Secondly, WeChat has reduced the predictability and controllability of College Students' Ideological and political education. The diversity of WeChat communication media and the instant of information releasing makes the same person give a very different comments in the same thing at different times. When educators can not fully understand the information of the educators in a comprehensive way, it is more difficult to predict and grasp the dynamic changes of the educators' ideas. Third, the characteristics of WeChat's self-media weakened the dominant position of the ideological and political education of college students. The role of experts and authority in the ideological and political education is gradually fading out, becoming an ordinary person who speaks in WeChat, and have equal status to all students. Once the values of the educator is challenged, the educator is unable to maintain the image of authority and truth in other ways, then the autonomy and independence of the educators will gradually be challenged and the dominant position of the educators will be weakened. 


\section{The Countermeasures to Carry Out the Ideological and Political Education for College Students by WeChat New Media}

Build the WeChat platform for the ideological and political education of College Students. First, establish school and various school departments WeChat platform. School and various school departments should set up the WeChat circle to release the students' learning and life related information. Using WeChat's instant react to publish the relevant information for student services, so that students can know the relevant information and work procedures, improving the service efficiency and quality, reducing the cost of information asymmetry. The free interactive mode of WeChat can also launch the campus construction, the campus rules and regulations, such as the reform of the students involved in the vital interests of the decision to discuss in the spirit and idea of democratic participation, so that the school construction management and development of the decision-making will be more democratic and more satisfactory. Second, establish a WeChat platform of the instructors and ideological and political theory course teacher. Counselor is a bridge between the students and the school, and in the normal learning and life, the counselor is the person who is the most likely to meet. Counselors and students' interest have a high degree of correlation, in some improper management, there even is a phenomenon that the student's scholarship and outstanding student cadres are determined by the instructor. Where there is a distribution of interests, there will be disputes. Disputes need to be communicated in order to facilitate the results of the two sides, and WeChat just provides such a platform for the exchange of equality and accessibility for the two sides. Third, establish WeChat platform for the leading experts. The leadership always gives people a feeling of superior. For example, for the understanding of the principals, many students see him on the opening ceremony, once see on the graduation ceremony, and there is no third times. For this scarce resources, WeChat just can solve it. If the students put forward the problem to the school leadership, as long as they can answer, the leaders have to answer, and they don't have time to answer because they are busy with their work, but in WeChat they can use the time to reply to question. Due to different professional skills, by WeChat, experts and scholars can meet the students' demand for knowledge, providing students with help, but also can communicate with the young students.

Increase WeChat's publicity efforts and improve WeChat's using skills. Educators should have a full and true understanding of WeChat itself. Awareness can not do without publicity, so colleges and universities can use newspaper publications, posters, campus columns and other ways to promote the WeChat, and it also can hold WeChat knowledge contest to deepen the understanding of college students, counselors, experts, professors and leaders on WeChat, promoting the application of WeChat in higher education. The Ministry of education attaches great importance to the use of WeChat skills, clearly puts forward the "WeChat writing" as one of the professional skills of college counselors. To let WeCha work effectively in the ideological and political education of college students, it is necessary for educators to fully understand the characteristics and functions of WeChat, so as to enhance the attention of WeChat.

Enrich the content of ideological and political education of college students and pay attention to their specific life. The university student's curiosity and curiosity are strong, so the events that occur in society tend to be the focus of their attention. For complex problems, the traditional ideological and political education can not solve, but WeChat can make the whole ideological and political education closer to life. WeChat, although only 150 words of space, covers a variety of content types, and WeChat can deliver fresh, timely, and popular content. College Students Ideological and political education workers put the latest hot topic or related controversial topic published to WeChat for analysis and discuss, in this way, students can realize the life and 
growth in the share of each one airs his own views. At the same time, the ideological and political education of college students should pay more attention to the education of the specific real life of the educated people of WeChat, making the work to do detailed, in-depth life details and into the daily life. For example, the issue of poverty subsidies for poor students, how to make grants to really help those in need? College students love is so common, but how to grasp the appropriate scale of love? If WeChat is concerned about these issues, it can bring a lot of help to college students' life.

\section{Conclusion}

As a popular new media, WeChat has brought great opportunities and challenges to the ideological and political education of college students. How to let the students make proper use of WeChat, has become an important problem in the ideological and political education. In the teaching practice, it should build the WeChat platform for the ideological and political education of college students, increase WeChat's publicity efforts and improve WeChat's using skills and enrich the content of ideological and political education of college students and pay attention to their specific life.

\section{Reference}

[1] Liu Hongyan, Wang Jing, Lin Yue. On the application of WeChat in Ideological and political education in private colleges and universities, [J]. theory, 2014,29:278-279.

[2] Chen Jing, Zhang Bing. Research on the Countermeasures of College Students' Implicit Ideological and Political Education under the environment of WeChat [J]. development of human resources, 2015,04:169-170.

[3] Nan Yanfeng. A new platform of Ideological and political education for College Students -WeChat [J]. theory, 2015,17:243-244.

[4] Feng Ziming. Analysis of the development strategy of Ideological and political education in university based on WeChat [J]. Journal of Jishou University (SOCIAL SCIENCE EDITION), 2014, S2:96-97.

[5] Zhu Qing. On the ideological and political education communication strategy of WeChat public platform in Colleges and Universities -- Taking the title as the angle of view [J]. Study on the News Herald, 2016,01:29+32. 